\title{
INNOVATION IN CREATIVE TECHNOLOGY: ACADEMIC AND CREATIVE ECONOMY
}

\author{
KHAIRUL AZHAR MAT DAUD* \\ ABU HASSAN HASBULLAH** \\ AHMAD RASDAN ISMAIL*** \\ NIK ZULKARNAEN KHIDZIR**** \\ SURIATINI ISMAIL*****
}

\begin{abstract}
Abstrak
Industri kreatif telah menjadi agenda utama kerajaan dalam mencapai wawasan 2020. Kewujudan Dasar Industri Kreatif Negara merupakan bukti bahawa kerajaan sangat serius dalam usaha untuk mengangkat martabat industri kreatif ke tahap yang lebih tinggi. Oleh itu, untuk memastikan hasrat kerajaan ini tercapai maka sistem pendidikan Negara juga perlu memainkan peranan untuk menyokong hasrat tersebut. Kurikulum pendidikan yang selari dengan Dasar Industri Kreatif Negara perlu diperkenalkan. Adalah dilihat, Fakulti Teknologi Kreatif dan Warisan merupakan satu-satu nya fakulti di negara ini yang menyokong hasrat tersebut. Selain daripada itu, FTKW juga dilihat akan menjadi sebuah pusat pengajian yang berteraskan kepada teknologi kreatif dan sangat relevan dengan keperluan masyarakat dan perkembangan ekonomi di abad ke 21 ini.
\end{abstract}

Kata Kunci: Industri Kreatif, Dasar Industri Kreatif Negara dan Pendidikan Kreatif

\begin{abstract}
The existing of National Creative Industry Policy existence is proof that government is serious in its efforts to uplift the creative industry to a higher level. In order to ensure the government's aspiration can be realised, national education is needed to play its role. Education curriculum which is parallel to the National industrial policy should be introduced. It can be seen that, Faculty of Creative Technology and Heritage is the only faculties in this country that supports this aspiration. Additionally, FTKW is expected to become a creative technology-based learning centre which is extremely relevant to the needs of the society and economic development in 21st century.
\end{abstract}

Key Words: Creative Industries, National Creative Industry Policy and Creative Education

* PhD,Timbalan Dekan di Fakulti Teknologi Kreatif \& Warisan, Universiti Malaysia Kelantan (UMK)

** PhD, Profesor dan Dekan di Fakulti Teknologi Kreatif \& Warisan, Universiti Malaysia Kelantan (UMK).

*** PhD,Profesor Madya dan Ketua Unit Pengurusan Persekitaran, Keselamatan Dan Kesihatan Pekerjaan UMK.

**** PhD, Timbalan Dekan di Fakulti Teknologi Kreatif dan Warisan, Universiti Malaysia Kelantan (UMK).

***** PhD, Penyelaras Program Senibina \& Ekistik di Fakulti Teknologi Kreatif \& Warisan, Universiti Malaysia Kelantan (UMK). 


\subsection{Introduction}

The Policy of National Creative Industry (DINK) (2009) has explained clearly the objectives to boost economy and social cultural at national level. The government's intention was explained in the eleven DIKN implementation strategy are;

1.1 Strengthening the capacity of human resources in the creative industries through specialized training, learning and creative activity. The action plan is to enhance the curriculum in institutions of higher education to meet the needs of the industries, as well as providing incentives allowances at secondary schools to higher education and provide appropriate training to players or to creative industry professionals.

1.2 Creating an environment conducive to the development of institutions, infrastructure and financial support in the form of incentives, and investment funds. The action plan is to set up the National Visual Arts Development Board as well as developing infrastructure in Dengkil, Selangor, National Music Complex and Heritage Gallery. Also allocate RM100 million as fund for production international joint venture for the next five years, with an allocation of RM20 million a year, to produce two international films and human capital development fund.

1.3 Ensure the product of Malaysian brand accepted in the local market and are able to compete in regional and international markets through continuous promotion. The action plan is to enter the creative product as a promotional agenda by the Malaysia External Trade Development Corporation in other countries besides creating Creative Trade Mission.

1.4 Increase the efforts of research and development continued in order to develop creative industries.

1.5 Promote innovation and use of technology, and increasing the local expertise towards the invention of product in creative industries. The action plan is to improve the use of technology in the production and marketing without compromising on the quality and originality of creative products.

1.6 Encourage the involvement of private companies, government-linked companies (GLCs) and multinational companies (MNCs) to continuously support in the development of creative industry. The action plan is to introduce the adoption program between the company and certain heritage buildings, encourage the inclusion of international creative companies to create career opportunities and the transfer of skills to local communities in the creative industries.

1.7 Emphasize strengthening of supporting industries downstream. The action plan is to sustain the downstream industry through the provision of funds, infrastructure and appropriate incentives. 
1.8 Ensure the management, implementation and enforcement of laws, acts, rules and copyright in order to strengthen the regulatory process for each product and the outcome of creative industry. The action plan is to create a new legal framework to coordinate, protect and develop local creative industry.

1.9 Develop new intellectual property as a business asset, the action to be taken is to intensify efforts towards the development of intellectual property as a business commodity.

1.10 Fostering an appreciation and a positive perception among the public about the image, and the future potential of the creative industry to be at par with other professional fields. The action plan is to create Arts activists welfare fund and Assistance Fund for National Art Gallery.

1.11 Utilizing creative institutions of government, non-governmental and non-governmental organizations as partners to develop the creative industries. (Bernama, October 23, 2011)

Based on the foundations laid down by DINK, it is seen that FTKW certainly will be a very important center of education and training for the 21st Century, which is the Period of Creative Economy or "Creative Futures" with the creative industries as one of the largest contributors in the sector "Future Economy "as stated by John Howkins (2001) in The Creative Economy; "Creativity as central to the emerging 21st century global economy" (2001). This is confirmed also by RA Mashelkar, former Director General, Council of Scientific and Industrial research, India; "We have seen economies based on agriculture, manufacturing and knowledge in the past but in the future the world economy will be solely based on creativity" when unfurled seminar titled "Only Right Education" at the 64th Foundation Day of the University of Pune (UoP) on February 10, 2013 in New Delhi, where India has one of the very rapid development of attention in the creative industries.

\subsection{Innovative Ecosphere}

Innovation means renewal or new items produced for use in the future. Innovation arising from an effort to improve an existing system or a product derived from the past and the problems arising from the current time. Innovation is really not a culture, but it is a philosophy in shaping a better future and excellence. Innovation can be produced through the diversity of knowledge, ie knowing the requirements, application, consumption, production processes, exhibition and distribution.

According to the Kamus Dewan Fourth Edition, innovation means something newly introduced, such as methods, systems, and other customs. According Ronger E. Miller (1971), innovation is an idea, practice or object that is considered new by someone. Spencer (1994) explains that innovation is considered a new and better than the old one by an individual. While in the Glossary of Educational Technology (1995) refers innovation as an idea, a concept or a new strategy that can improve a practice. Sufean Hussin (2001) in his paper at the Seminar on Education Policy and Management of state innovation means renewal, 
modification, or repair of ideas, materials, science and the creation of art and culture of civilizations with the purpose of fulfilling specific functions or particular tastes or meet specific market.

Fostering a culture of innovation in higher education institutions among citizens (IPT) consisting of academics, non-academic staff and students need to support the development of innovative ecosphere nature of innovative activity.

Ecosphere formed by the combination of the diversity of ecosystems in an institution. The ecosystem of an organization formed from the beginning of the organization is governed and managed. The efficient management and practice the holistic of management system will create a good, effective and efficient ecosystem. Open management and strive to achieve the objectives, mission and vision of the organization, will always strive to make improvements from time to time by the views and efforts of all staff in the organization.

Through the competent and perfect governance, innovative culture among all academicians, nonacademics and students will be emerge indirectly. Formation of culture, rules, guidelines, standard procedures and policies of the organization will create a particular ecosystem in the organization. AG Tansley (1935) defines ecosystem as the relationship between structure and function. Structure referred to in the definition of these ecosystems is related to the uniformity of species (species diversity).

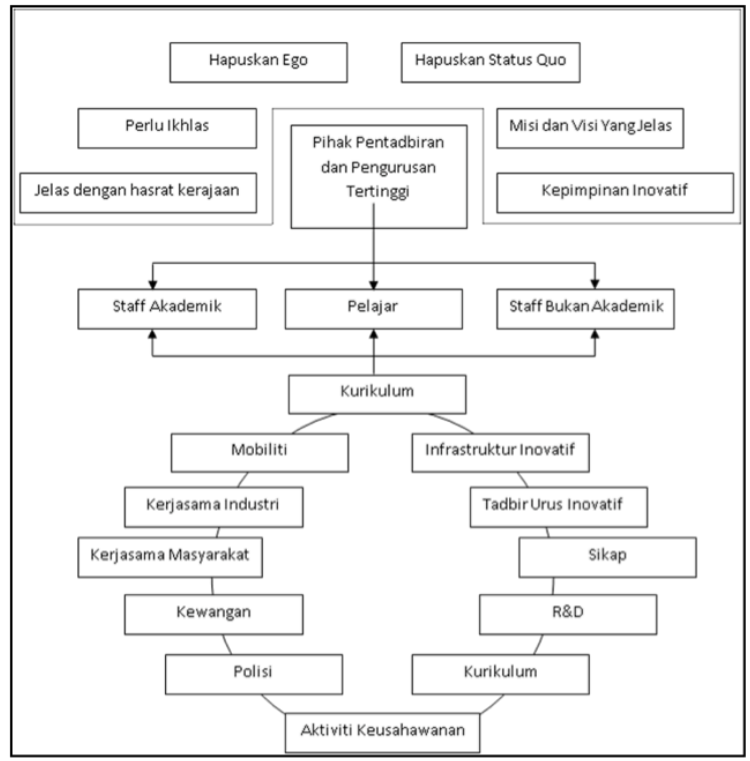

Figure 1: The conceptual to Building an Ecosphere of Innovation 


\subsection{Innovation in Creative Technology}

The field of studies before 21st century give a lot of emphasis on the fields of study that do not relate to each other. The diversity of fields in studies has been separated for a long time. Studies in science and technology emphasis on the logical fact. Meanwhile, the arts and humanities discuss aspects of the abstract. This field of knowledge is rarely met. The field-oriented methods of study produce students who are not creative. Many inventions developed by researchers from various fields. The science and technology has created a variety of tools based on science and technology. There are various devices have been invented for the use and convenience of mankind. However, this equipment developed ergonomic and aesthetic factors.

Meanwhile, artist has been producing a variety of models and product prototypes for humanity used, whether in the form of illustrations, sculpture or mock ups. These products are very attractive, but they are only being applied as ornamentals and souvenirs. The products could not be used because they do not work as expected. These products are developed based on human imagination alone.

Therefore, it is very important to integrate the two domains of the knowledge which will contribute onto meaningful form. The clash between science and technology with arts and humanities obviously appear at the beginning of the 21 st century. Development of the car for example is no longer based solely on technology but is more closely related to the design of ergonomic and aesthetic aspects. Figure 2 shows how creative technology arising from the convergence and integration processes in the field of science and technology with arts and humanities.

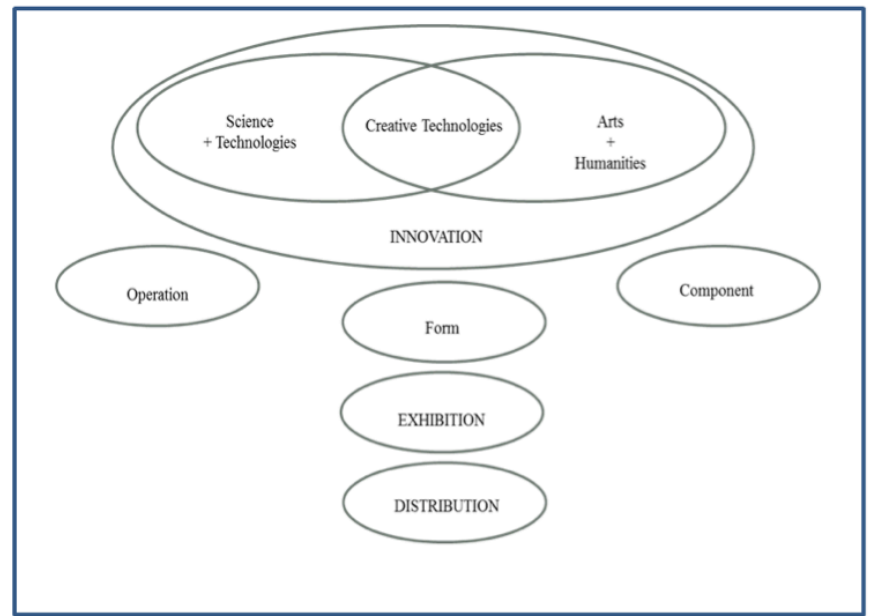

Figure 2: The Emerging of Creative Technologist 


\subsection{Monsun Model}

According to Abu Hassan Hasbullah (2013), professor of creative futures stated that innovation can be created by five major phases. The first is through the novelist ideas. The novel idea will be able to making improvements to the system or whether an existing product, then the idea was developed to development. The second phase is planned to realize the idea. The third phase is the implementation of a product or system development. The fourth phase is the exhibition of products or spreading systems to be implemented. The fifth phase is the distribution system and, sixth phase is the evaluation of a product or system innovation implemented. Model introduced by Abu Hassan Hasbullah known as the monsun model and has been implemented in the Faculty of Creative Technology and Heritage, Universiti Malaysia Kelantan.

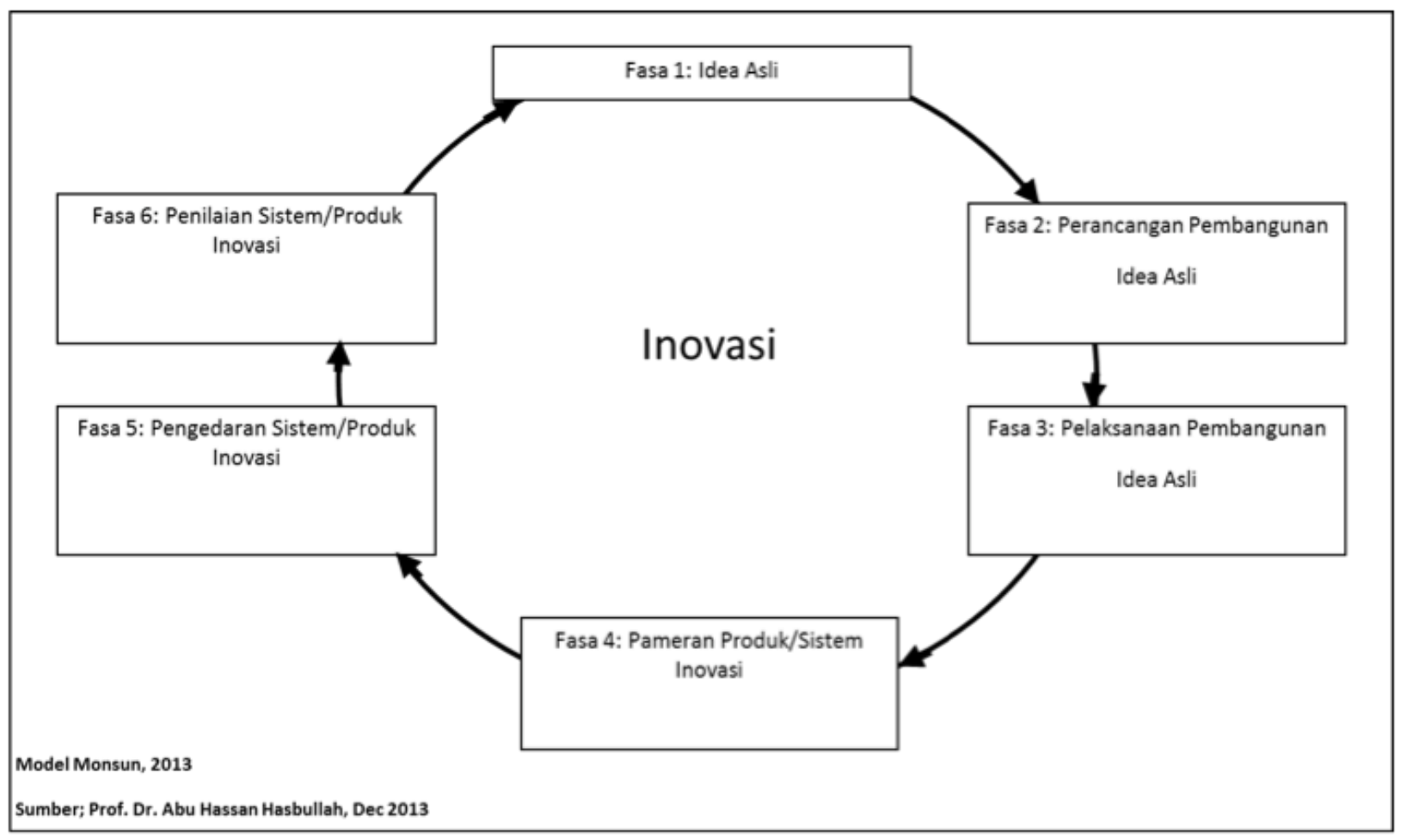

Figure 3: Monsun Model

Source: Abu Hassan, Dec 2013 


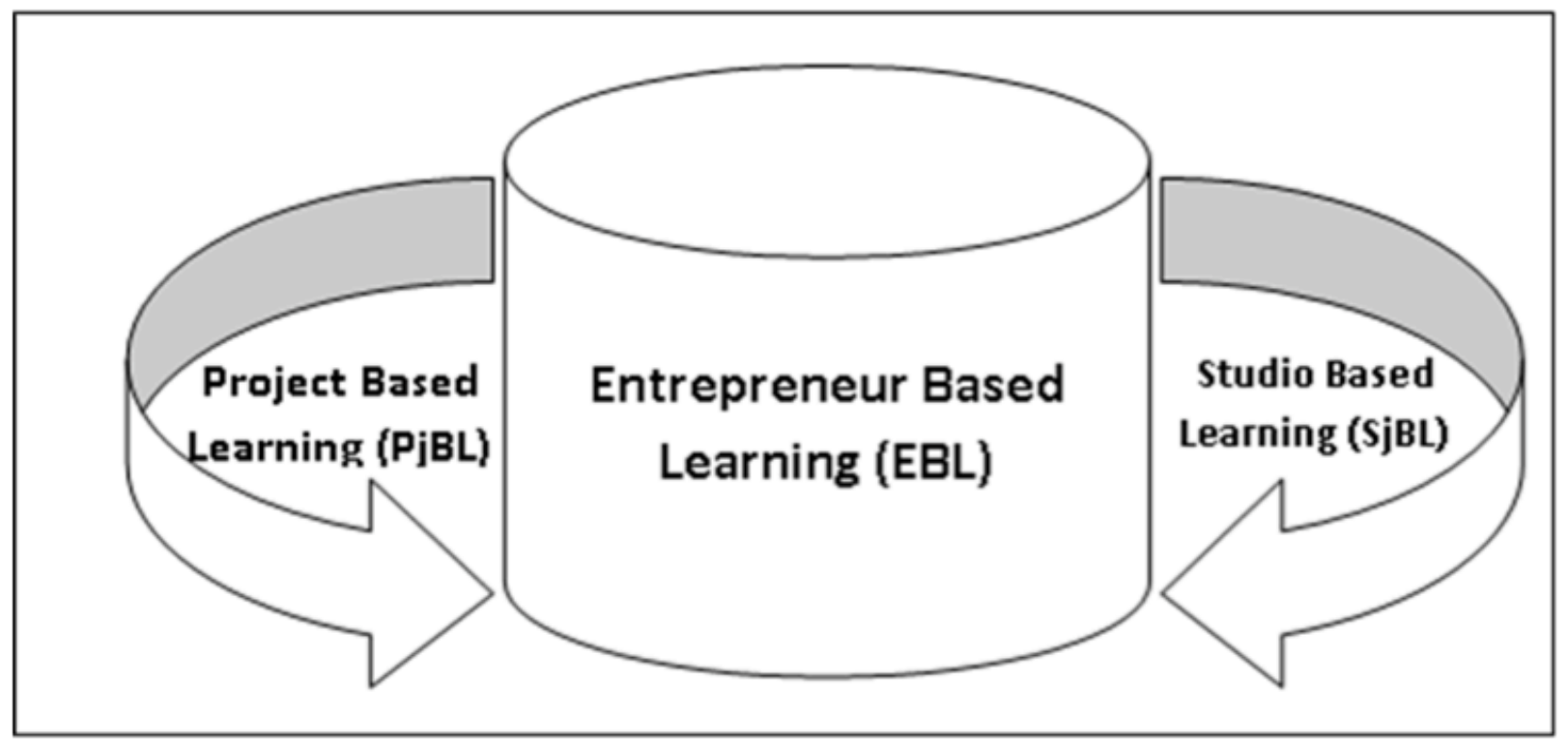

Figure 4: Entrepreneur Based Learning (EBL)

The development and the implementation of entrepreneurship education programs for pupils, however, linked with many specific challenges. For example, pupils often not allowed to start up their own companies or may not have full control over their financial situation. Moreover, career choices may be part of some distant future for teenagers. As a result, educational initiatives aimed at stimulating entrepreneurship can be perceive by teenagers as irrelevant, or can be long forgotten by the time actual career choices have to be made (Peterman and Kennedy 2003; Lepoutre et al. 2010). Entrepreneur reality-based learning was been found that ideal to apply in the studio based learning approach. In studio-based learning, students were provides with problems or project to be developed. Students were been allowed to plan and design their project themselves. Students need to get an approval from the lecturers to proceeds their design before they develop it. Students will develop their works as they planned and designed. Students will implement their projects either individually or in groups.

Through this method, students will be master and improve their soft skills such as communications skills, discussion skills, organize skills, decision-making skills and so on. Therefore, entrepreneur's characteristic is very crucial to instilled into the students whose will be live in the challenging atmosphere in 21st century (Veronica and Jackson, 2011). To realize the government's aspiration to produce students who not only 
have a high level of soft skills, but also a features of superior entrepreneur such as determination, perseverance, courage, willingness to facing with any risk and so on, thus the entrepreneur-based learning is seen very important to applied among students. Entrepreneur-based learning will be able to implement through the proper planned.

\subsection{The Evolution of Creative Industries}

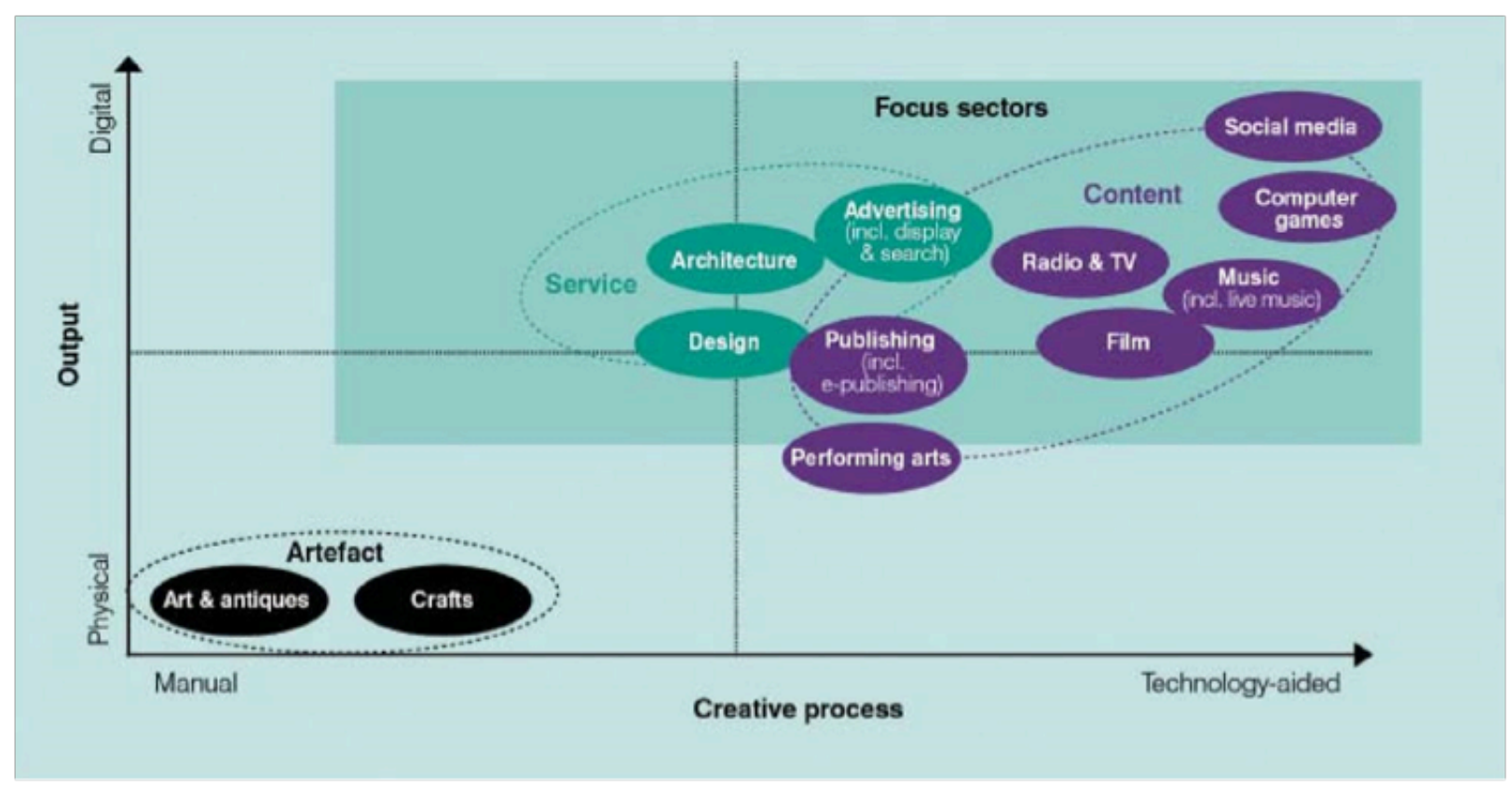

Figure 5: The evolution of creative industries; From Physical to Digital Source: Abu Hassan et. al, 2014 


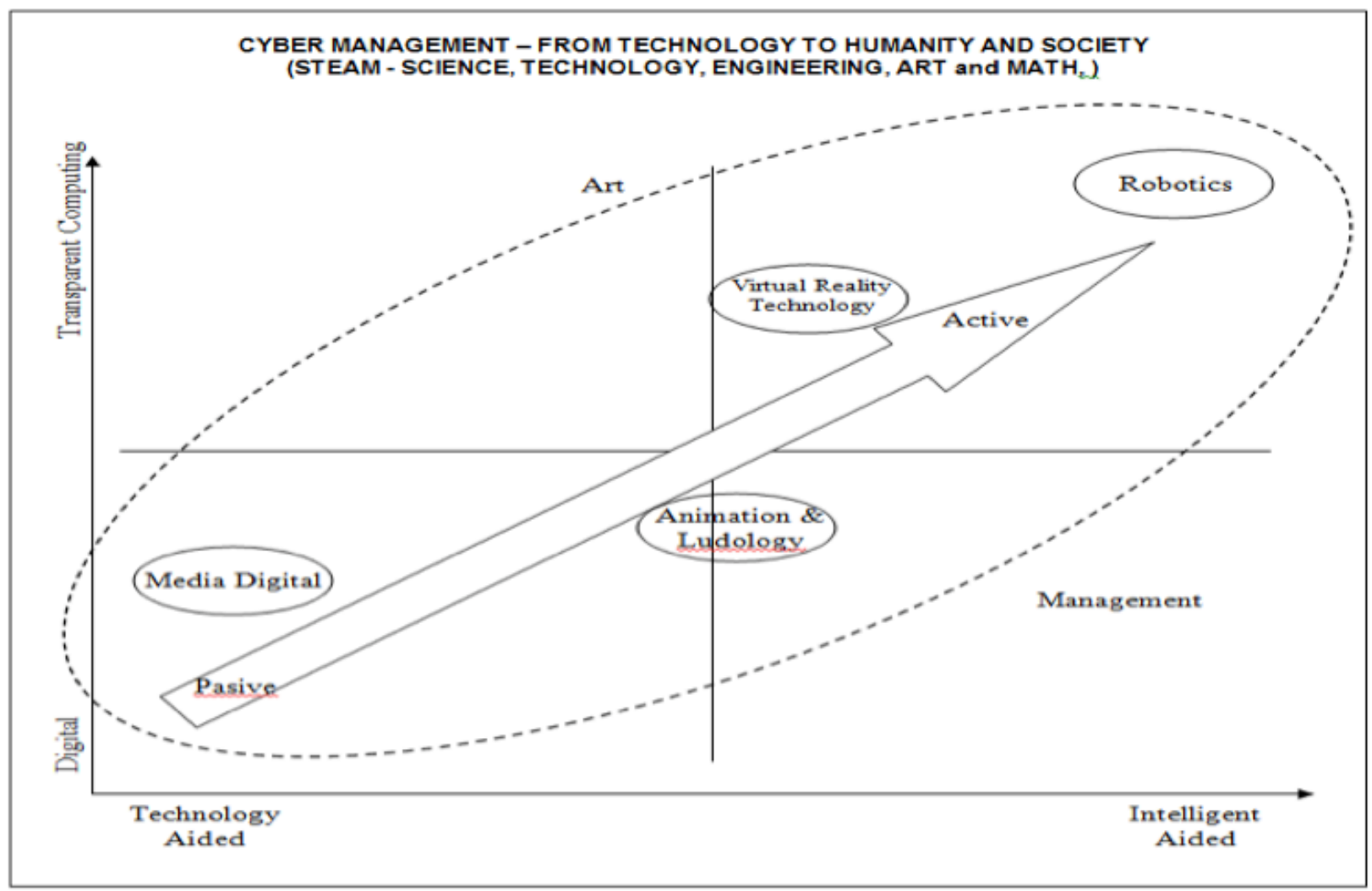

Figure 6: The evolution of creative industries; From Digital to Transparent Computing Source: Abu Hassan et. al, 2014

\subsection{Technologist in Creative Industries}

The creative technologist has a strong technological background (read computing, engineering, or whatever is appropriate for the organisation). They have a very logical, rational, analytical, scientific and objective outlook and are highly left-brain active. They are however also very right-brain active and are intuitive, subjective, holistic, and synthesizing. This sort of combination is partly learned but I believe you are also naturally pre-disposed to it. Interestingly Prof. Ronald Standler says that highly intelligent and creative people often get average grades. I think that a certain amount of distraction is natural, because you are able to look at something in such a large number of ways. In many agency environments, the creative technologist bridges the gap between "creative" and "technology". 


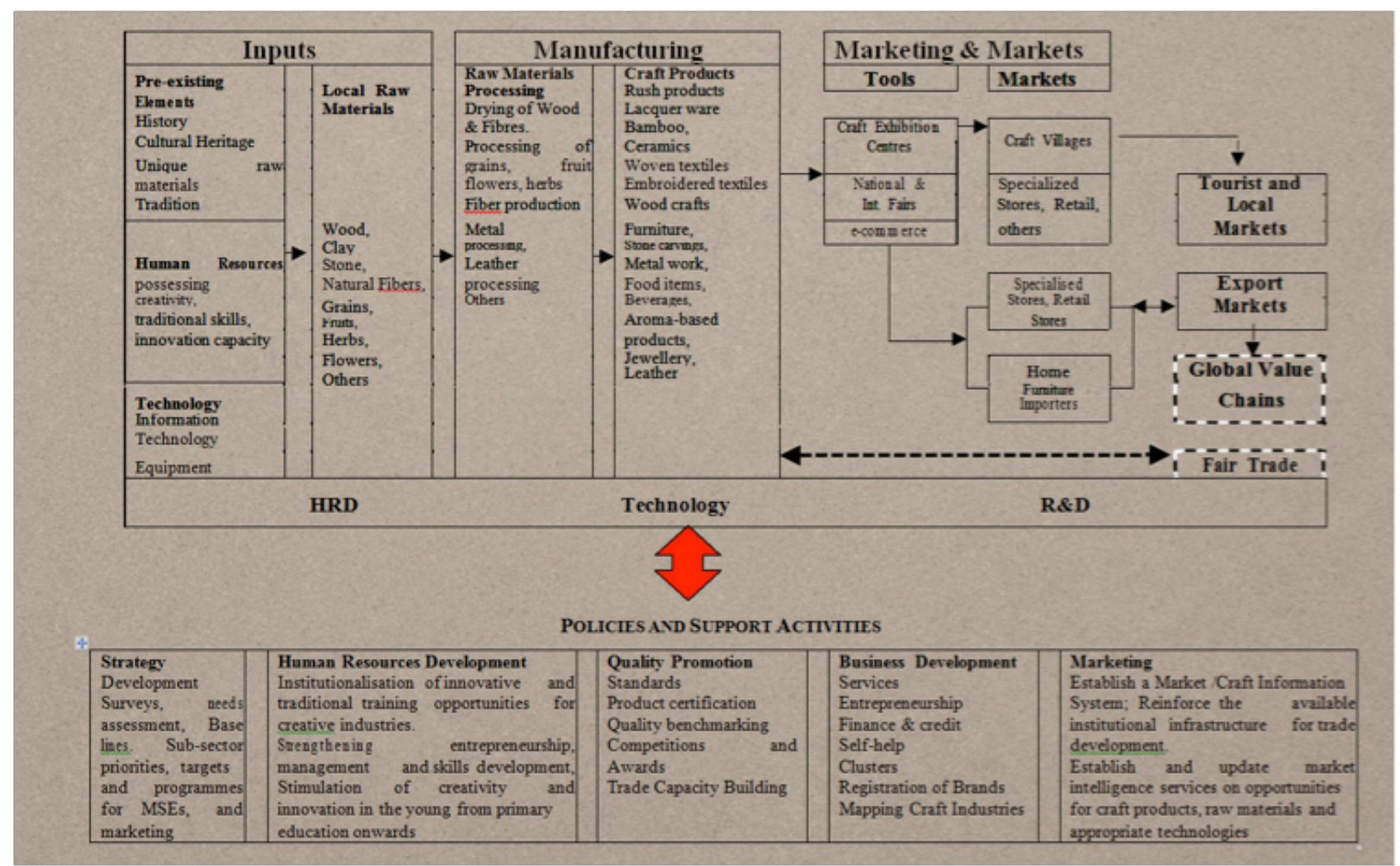

Source: Abu Hassan Hasbullah, 2013

\subsection{Conclusion}

In the 21st century, creative artwork could not longer stand alone. Development of creative artwork should be developed using the technology. Therefore, all artist in creative industries need to master in science and technology other than art. However, competition for careers and advancement of knowledge in the 21 st century has sought the mankind to capture a multidiscipline knowledge. Possession multidiscipline of knowledge which is the basis of the knowledge is obviously different may have a high level of possibility to produce the perfect community.

Mastery of academic disciplines based on facts and abstract can train someone to optimize the use of the right brain and left brain balanced. Balance the use of the right brain and left brain will produce a balanced and perfect human with mind and emotions. Technology, Science, Computer, Mathematics and Art is an

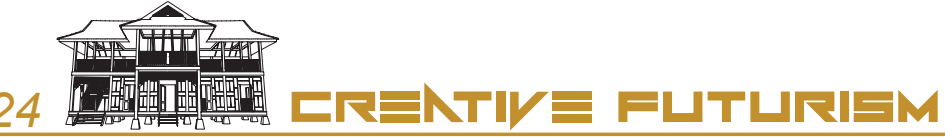


interdependent knowledge in creative industry. Creative industries couldn't develop without technology. Therefore, the education of creative technology developed and introduced in the Faculty of Creative Technology and Heritage (FTKW), Universiti Malaysia Kelantan (UMK). Is expected in the 21st century, all the players in creative industries will begin to focus on FTKW as a hub of excellence in promoting creative industries through the use of the latest technology. Every student who wishes to master in creative must also acquire knowledge of technology.

\section{References}

Arifatul Husna, M.A., Zainol, B., Zakiyah, S., \& Adura, A. (2010). Predicting Entrepreneurial Intention Among Malay University Accounting Students in Malaysia. Unitar e-Journal. Retrieved July 24, 2010, from http://ejournal.unirazak.edu.my/articles/Predict ing_Entrepreneur_p1v6n1Jan10.pdf.

Ahamad Tarmizi Azizan, Ab. Aziz Shuaib dan Fauzi Ab Llah, (2010). Makyong Dua Indera: Ekplorasi Kreatif Menerusi Animasi. umkeprints.umk.edu.my/317/1/Paper\%203.pdf.

Albury D (2005): "Fostering innovation in public services”, Public Money and Management 25: 51-56

Azlan, A.B. (2009, November 17). Getting more grads to become entrepreneurs. The New Straits Times, p.B7.

Arifatul Husna, M.A., Zainol, B., Zakiyah, S., \& Adura, A. (2010). Predicting Entrepreneurial Intention Among Malay University Accounting Students in Malaysia. Unitar e-Journal. Retrieved July 24, 2010, from http://ejournal.unirazak.edu.my/articles/Predict ing_Entrepreneur_p1v6n1Jan10.pdf.

Bengt-Åke Lundvall (2007). Higher Education, Innovation And Economic Development, Department Of Business Studies. Paper To Be Presented At The World Bank's Regional Bank Conference On Development Economics, Beijing, January 16-17, 2007.

Christensen, J. L. and Lundvall, B.-Å. (eds.) (2004), Product Innovation, Interactive Learning and Economic Performance, Amsterdam, Elsevier, forthcoming.

Caroline, V., \& Rémi, B. (2006). Developing an Entrepreneurial Spirit among engineering college students: what are the educational factors? In A. Fayolle and H. Klandt (eds.) International Entrepreneurship Education Issues and Newness. Retrieved September 20, 2013, from http://rb.ec-lille.fr/perso/papers/E_ Elgar_chapter_project_ 
Dahlan, I., Hakimin, Y., dan Azwin, N. (2010). "The Realtionship Between Tacit Knowledge and Entrepreneurial Itentions Among University Students", Etrepreneurial Education and Entrepreneurship in Malaysia : Book of Readings., Vol.1, p. 26-38.

Gilbert, D. (2010). Integrating Theory and Practice for Student Entrepreneurs: An Applied Learning Model. Journal of Enterprising Culture, 18(1). 83-106.

Hatten T.S., \& Ruhland, S.K. (1995). Student attitude toward entrepreneurship as affected by participation in an SBI program. Journal of Education for Business, 70(4), 224-227.

Hollanders H (2007): "Measuring service innovation: service sector innovation index", Six Country Programme Workshop presentation, Karlsruhe, Germany

Jones, C. and English, J. (2010) "A Contemporary Approach To Entrepreneurship Education", Education + Training, Vol.46, No. 8/9, pp. 416-423

L., Anderson, M., \& Brown, W. (2006). Are engineers becoming more enterprising? A study of the potentials of entrepreneurship education. International Journal of Continuing Engineering Education and Life Long learning, 16(5), 355-365.

London School of Economics Public Policy Group (2008): "Innovation in Government Organizations, Public Sector Agencies and Public Service NGOs", NESTA Working Papers September 2008, London- UK

Majlis Kerjasama Ketua-Ketua Pusat Pengajaran Dan Pembelajaran Institut Pengajian Tinggi Awam Malaysia (Magnetic) 2012; Amalan Terbaik Pengajaran Dan Pembelajaran Di Institusi Pengajian Tinggi Awam Malaysia. Penerbit Utmpress Universiti Teknologi Malaysia, 81310 Utm Johor Bahru, Johor Darul Ta'zim, Malaysia.

Mohd Dahlan Ibrahim, Ghazali Ahmad, Mohd Rafi Yaacob, (2010). Etrepreneurial Education and Entrepreneurship in Malaysia : Book of Readings., Vol.1. Kota Bharu : FKP, UMK.

Mohd Fairuz, R. (2006). Kesediaan Bakal Graduan Hotel dan Katering Politeknik Dalam Menceburi Bidang Keusahawanan Katering. [Unpublished master's project report). Universiti Tun Hussein Onn, Johor, Malaysia.

Mohd Nizam, A.R., Norhamidi, M., Dzuraidah A.W., Jaharah, A.G., Nishata Royan, R.R., \& Shahida Azura, M.A. (2009). Engineering Students towards Entrepreneurship Awareness. Seminar Pendidikan Kejuruteraan dan Alam Bina (PeKA'09). Retrieved June 10, 2010 from http://pkukmweb.ukm.my/ upak/ pdffile/PeKA 09/P4/33.pdf 
Mohd Zahari, I. (2010). Developing Entrepreneurship Education: Empirical Findings from Malaysian Polytechnics. (Doctoral dissertation, The University of Hull, United Kingdom). Retrieved July 10, 2010 from https://edocs.hull.ac.uk/muradora/objectView!getDataStreamContent.action?pid=hull:2682\&dsid $=$ document.pdf\&mimeType=application $/$ pdf

Nor Azizah Salleh, Siti Rahayah Ariffin Dan Musa Daia (2010). Penerapan Nilai Murni Melalui Pembelajaran-Kooperatif dalam Sains. Diperolehi daripada: Murni MJeulranluail PPeemndbiedliakjaanra 2n7- K(2o0o0p1e)r a4t7if -d 5a7lam Sains 47

OECD (2009): "Working out change: Systemic Innovation in Vocational Education and Training", OECD/ CERI, Paris, France

Profesor Dato' Omar Osman (2013). “Mensinergi Ekosfera Untuk Kecemerlangan Universiti” Teks Perutusan Naib Canselor Universiti Sains Malaysia (Usm), Pada Hari Khamis, 10 Januari 2013, Jam 9.30 Pagi Di Dewan Tuanku Syed Putra Usm Pulau Pinang, Jumaat, 11 Januari 2013, Jam 9.30 Pagi Di Kampus Kejuruteraan \& Ahad 13 Januari 2013 Jam 2.00 Petang Di Kampus Kesihatan.

Pelan Strategik Pengajian Tinggi Negara Melangkaui Tahun 2020

Tan, S. T, Ng, and Ng, C. K. F. (2010) "A Problem-based Learning Approach to Entrepreneurship Education”, Education +Training, Vol. 48, No. 6, pp. 416-428

Verzat_Bachelet.pdf Fewer unemployed graduates expected. (2009, July 22). The New Straits Times, p.2. Galloway,

Wang, C.K, \& Wong P.K. (2004). Entrepreneurial interest of university students in Singapore. Technovation, 24(2), 163-172.

Yar Hamidi, D., Wennberg, K., \& Berglund, H. (2008). Creativity in Entrepreneurship Education. Journal of Small Business and Enterprise Development. 15(2), 304-320.

Zahariah M.Z, Amalina M.A., \& Erlane, K. G. (2010). Entrepreneurship Intention Among Malaysian Business Students. Canadian Social Science, 6(3),34-44. 